\title{
POTENSI SITOTOKSIK EKSTRAK AIR DAUN SIRIH HITAM (Piper sp.)
}

\author{
Nadia Rahma Kusuma Dewi*, Hadi Kuncoro, Laode Rijai \\ Laboratorium Penelitian dan Pengembangan FARMAKA TROPIS, Fakultas Farmasi, Universitas Mulawarman, \\ Samarinda, Kalimantan Timur \\ *email: nadia_rahma@rocketmail.com
}

\begin{abstract}
ABSTRAK
Penelitian potensi sitotoksik ekstrak air daun sirih hitam (Piper sp.) dilakukan berdasarkan hasil penelitian kandungan metabolit sekunder dan bioaktivitas terhadap Artemia salina Leach ekstrak daun sirih hitam (Piper sp.). Uji bioaktivitas dilakukan dengan metode Brine Shrimp Lethality Test (BSLT) terhadap Artemia salina Leach. Ekstrak daun sirih hitam telah diekstraksi menggunakan pelarut air dengan metode panas (rebusan). Hasil pengujian potensi sitotoksik ekstrak air daun sirih hitam menunjukkan nilai $\mathrm{LC}_{50}$ pada ekstrak daun sirih hitam muda 69,18 ppm dan ekstrak daun sirih hitam tua 5,13 ppm.
\end{abstract}

Kata kunci : Sitotoksik, Piper sp., Metode panas

\section{PENDAHULUAN}

Pemakaian obat bahan alam untuk pengobatan telah lama dipraktekkan oleh masyarakat Indonesia karena hasil dan manfaatnya telah dapat dirasakan langsung. Oleh sebab itu tidaklah mengherankan jika penggunaan obat bahan alam cenderung meningkat dari waktu ke waktu. Hal ini dapat dilihat dengan semakin meningkatnya pemakaian jamu oleh masyarakat, di sisi lain Industri obat bahan alam terus berkembang. Agar penggunaannya optimal, perlu diketahui informasi yang memadai tentang kelebihan dan kelemahan serta kemungkinan penyalahgunaan obat tradisional dan tanaman obat (Rahmadhani, 2009).

Salah satu usaha yang dapat ditempuh untuk menggali sumber obat nabati adalah menemukan obat kanker. Pengembangan obat antikanker dari bahan alam menjadi sangat penting karena sebagian besar obat antikanker yang ada saat ini selain bersifat antiproliferatif terhadap sel kanker juga terhadap sel normal. Karena sifat itulah maka obat antikanker ini mempunyai indeks terapi sempit dan selektivitas rendah, di samping itu timbulnya resistensi terhadap berbagai obat antikanker tidak dapat terhindari.

Banyak penelitian dilakukan untuk mencari senyawa antikanker baru dengan harapan sifat yang lebih baik. Selektivitas suatu obat dapat digunakan sebagai tolak ukur baik dan buruknya suatu obat serta keamanannya. Selektivitas obat antikanker dapat diukur dengan cara menghitung indeks selektivitas (IS) yaitu menghitung $\mathrm{IC}_{50}$ sel normal dibagi dengan $\mathrm{IC}_{50}$ sel kanker (Badisa et al., 2009). Semakin besar angka indeks selektivitas obat antikanker yang ada saat ini, artinya efek samping yang ditimbulkan cukup banyak, menyebabkan penderita kanker banyak yang menghentikan kemoterapi. Efek samping yang sering muncul pada obat antikanker adalah alopecia (kerontokan rambut), mual, emesis (muntah), anemia, toksisitas pada liver, dan induksi kanker di organ lain. Hal inilah yang mendorong masyarakat berbondong-bondong datang ke pengobat tradisional atau pengobatan herbal untuk mengurangi dan menghilangkan penderitaannya. Banyak 
sekali obat herbal Indonesia telah digunakan secara tradisional untuk mengatasi penyakit kanker. Namun demikian, usaha untuk mencari antikanker baru dari bahan alam masih terus dilakukan secara intensif oleh para peneliti/akademisi (Wahyuningsih, 2010).

Telah dilakukan penelitian sitotoksik terhadap daun sirih hitam menggunakan metode ekstraksi yaitu maserasi dimana sampel yang telah kering diekstraksi menggunakan pelarut organik yaitu etanol sehingga diketahui data nilai $\mathrm{LC}_{50}$ dari daun sirih hitam dengan pelarut etanol yaitu 5,741 ppm, fraksi $n$-heksana 2,460 ppm, dan fraksi etil asetat $0,925 \mathrm{ppm}$. Berdasarkan hasil penelitian, daun sirih hitam teridentifikasi mengandung golongan senyawa alkaloid, flavonoid, tanin, saponin, senyawa fenol, karatenoid, dan steroid yang diduga memiliki potensi sitotoksik (Hastuty, 2011).

Senyawa-senyawa yang menunjukkan ketoksikan yang tinggi dapat dikaitkan dengan potensinya sebagai antikanker atau kematian sel kanker. Skrining terhadap beberapa tanaman yang berpotensi sebagai antikanker telah dilakukan menggunakan metode Brine Shrimp Lethality Test (BSLT) pada larva Artemia salina Leach yaitu suatu metode bioassay yang mudah, cepat, murah, dan dapat dipercaya (Meyer, BN et al, 1982). Metode ini telah banyak dimanfaatkan untuk berbagai keperluan antara lain mencari keberadaan senyawa antikanker karena sifat toksiknya.

Ditinjau berdasarkan data tersebut, jika pelarut etanol diganti menggunakan pelarut air kemungkinan dapat memberikan aktivitas biologi dimana dari segi kepolaran pelarut air memiliki nilai konstanta dielektrik lebih besar daripada pelarut etanol. Senyawa polar yang terekstraksi di dalam air, tidak mungkin terekstraksi oleh pelarut etanol karena kepolaran etanol masih di bawah air sehingga memungkinkan adanya perbedaan kandungan kimia yang terekstraksi. Sehubungan dengan itu perlu dilakukan penelitian ekstrak air dengan cara panas karena karena hal ini penting jika terbukti baik dengan cara perebusan sirih hitam dapat memberikan khasiat.

Pertimbangan pemilihan air adalah untuk mengetahui bioaktivitas dari tanaman ini berdasarkan pemanfaatannya sebagai obat tradisional di masyarakat dilakukan dengan cara perebusan dengan air. Penggunaan daun sirih hitam sebagai obat tradisional masih jarang, hal ini yang mendorong peneliti mengkaji tanaman sirih hitam (Piper sp.) penggunaannya secara umum sebagai obat tradisional dengan melihat perbedaan aktivitas antara daun muda dan tua.

Penelitian ini bertujuan untuk mengetahui potensi sitotoksik ekstrak air daun sirih hitam (Piper sp.) terhadap larva udang laut Artemia Salina Leach dengan menggunakan metode Brine Shrimp Lethality Test (BSLT).

\section{METODE PENELITIAN}

\section{Bahan}

Bahan yang diteliti adalah simplisia daun sirih hitam (Piper sp.) bagian daun muda dan daun tua. Pelarut air digunakan untuk proses ekstraksi. Larva udang Artemia salina Leach bioindikator uji. Ragi untuk sumber makanan larva udang Artemia salina Leach. Air laut untuk media penetasan dan tempat hidup bioindikator uji. 


\section{Alat}

Alat-alat yang digunakan pada penelitian adalah blender, desikator vakum, panci tanah, neraca analitik (Precisa XB 4200 $C^{\circledR}$, Precisa XT $220 A^{\circledR}$ ), botol selai, batang pengaduk, gelas kimia, gelas ukur, labu ukur, pipet tetes, cawan porselin, spatula, aluminium foil, botol vial, penangas air, kaca aquarium, aerator, seperangkat alat penerangan, mikro pipet.

\section{Prosedur Pengujian Penelitian}

Pengujian potensi sitotoksik ekstrak air daun sirih hitam. Larva udang Artemia salina Leach ditetaskan dalam wadah pembiakan yang berisi air laut dan digunakan setelah 48 jam dari waktu penetasan. Vial uji dikalibrasi sebanyak 5 mL. Larva udang Artemia salina Leach 10 ekor dimasukkan ke dalam masing-masing vial yang berisi ekstrak dengan berbagai konsentrasi. Konsentrasi uji yang digunakan yaitu 5 ppm, 25 ppm, 50 ppm, 100 ppm, 75 ppm, dan 100 ppm untuk ekstrak daun sirih hitam muda. Konsentrasi uji yang digunakan yaitu $0,5 \mathrm{ppm}, 1 \mathrm{ppm}$, 2 ppm, 4 ppm, 8 ppm, 16 ppm, dan 32 ppm untuk ekstrak air daun tua. Dibuat stok ragi sebagai sumber makanan bioindikator uji. Ke dalam vial-vial tersebut dimasukkan 1 tetes ragi. Vial-vial uji kemudian disimpan di tempat yang cukup mendapat sinar lampu. Pengamatan dilakukan selama 24 jam dan dihitung jumlah larva yang mati. Jumlah larva udang Artemia salina Leach yang mati dicatat dan dihitung $\mathrm{LC}_{50}$ dengan menggunakan analisis Reed and Muench.

\section{HASIL DAN PEMBAHASAN}

Terlihat pada Gambar 1. terjadi peningkatan konsentrasi ekstrak air daun sirih hitam muda dalam kemampuan membunuh hewan uji larva udang, yaitu dengan bertambahnya larva udang yang mati. Ini terlihat dari hasil analisis dengan metode Reed and Muench dengan nilai $\mathrm{LC}_{50}$ 69,18 ppm (Tabel.3). Estimasi nilai $\mathrm{LC}_{50}$ dapat terlihat pada grafik titik pertemuan antara akumulasi kematian dengan akumulasi yang hidup. Hasil log dari $\mathrm{LC}_{50} 69,18 \mathrm{ppm}$ adalah 1,84 . Sumbu ini berada pada grafik antara log konsentrasi 1,699 - 1,875 seperti yang terlihat pada grafik. Hasil perhitungan batas kepercayaan angka $\mathrm{LC}_{50}$ berada antara range 1,78 - 1,9 dengan ukuran kesalahan sebesar 0,03. Berdasarkan nilai $\mathrm{LC}_{50}$ ekstrak air daun sirih hitam muda menunjukkan bahwa ekstrak air daun sirih hitam muda kurang berpotensi sebagai antikanker melainkan berpotensi sebagai antimikroba ( $\left.\mathrm{LC}_{50} 30-200 \mathrm{ppm}\right)$.

Tabel 1. Hasil Uji Ekstrak Air Daun Sirih Hitam Muda Terhadap Larva Udang Artemia salina

\begin{tabular}{cccccccc}
\hline \multirow{2}{*}{$\begin{array}{c}\text { Konsentrasi } \\
(\mathbf{p p m})\end{array}$} & Log & \multicolumn{2}{c}{ Jumlah } & \multicolumn{2}{c}{ Terakumulasi } & \multicolumn{2}{c}{ Rasio } \\
mati : total & $\begin{array}{c}\text { Mortalitas } \\
(\%)\end{array}$ \\
\cline { 3 - 8 } & Konsentrasi & Mati & Hidup & $\begin{array}{c}\text { Mati } \\
(\mathbf{x})\end{array}$ & $\begin{array}{c}\text { Hidup } \\
(\mathbf{y})\end{array}$ & $\begin{array}{c}\text { Terakumulasi } \\
\mathbf{x}:(\mathbf{x}+\mathbf{y})\end{array}$ & $\begin{array}{c}\text { Rasio } \mathbf{x} \\
\mathbf{1 0 0} \%\end{array}$ \\
\hline 5 & 0,699 & 2 & 28 & 2 & 97 & 0,02 & 2 \\
25 & 1,398 & 5 & 25 & 7 & 69 & 0,092 & 9,2 \\
50 & 1,699 & 10 & 20 & 17 & 44 & 0,279 & 27,9 \\
75 & 1,875 & 14 & 16 & 31 & 24 & 0,564 & 56,4 \\
100 & 2 & 22 & 8 & 53 & 8 & 0,869 & 86,9 \\
\hline
\end{tabular}




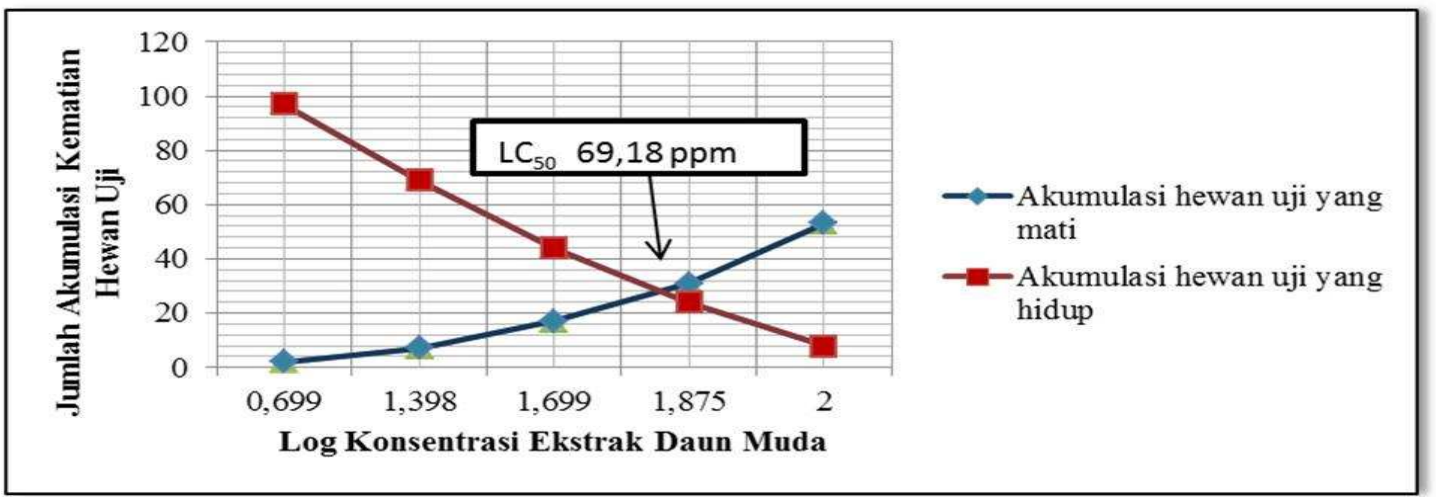

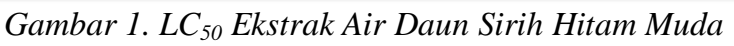

Tabel 2. Hasil Uji Ekstrak Air Daun Sirih Hitam Tua Terhadap Larva Udang Artemia salina

\begin{tabular}{cccccccc}
\hline \multirow{2}{*}{$\begin{array}{c}\text { Konsentrasi } \\
(\mathbf{p p m})\end{array}$} & Log & \multicolumn{2}{c}{ Jumlah } & \multicolumn{2}{c}{ Terakumulasi } & $\begin{array}{c}\text { Rasio } \\
\text { mati : total }\end{array}$ & $\begin{array}{c}\text { Mortalitas } \\
(\%)\end{array}$ \\
\cline { 3 - 8 } & Konsentrasi & Mati & Hidup & $\begin{array}{c}\text { Mati } \\
(\mathbf{x})\end{array}$ & $\begin{array}{c}\text { Hidup } \\
(\mathbf{y})\end{array}$ & $\begin{array}{c}\text { Terakumulasi } \\
\mathbf{x}:(\mathbf{x}+\mathbf{y})\end{array}$ & $\begin{array}{c}\text { Rasio x } \\
\mathbf{1 0 0} \%\end{array}$ \\
\hline 0,5 & $-0,301$ & 3 & 27 & 3 & 115 & 0,025 & 2,5 \\
1 & 0 & 6 & 24 & 9 & 88 & 0,093 & 9,3 \\
2 & 0,301 & 9 & 21 & 18 & 64 & 0,219 & 21,9 \\
4 & 0,602 & 13 & 17 & 31 & 43 & 0,419 & 41,9 \\
8 & 0,903 & 16 & 14 & 47 & 26 & 0,644 & 64,4 \\
16 & 1,204 & 19 & 11 & 66 & 12 & 0,846 & 84,6 \\
32 & 1,505 & 29 & 1 & 95 & 1 & 0,989 & 98,9 \\
\hline
\end{tabular}

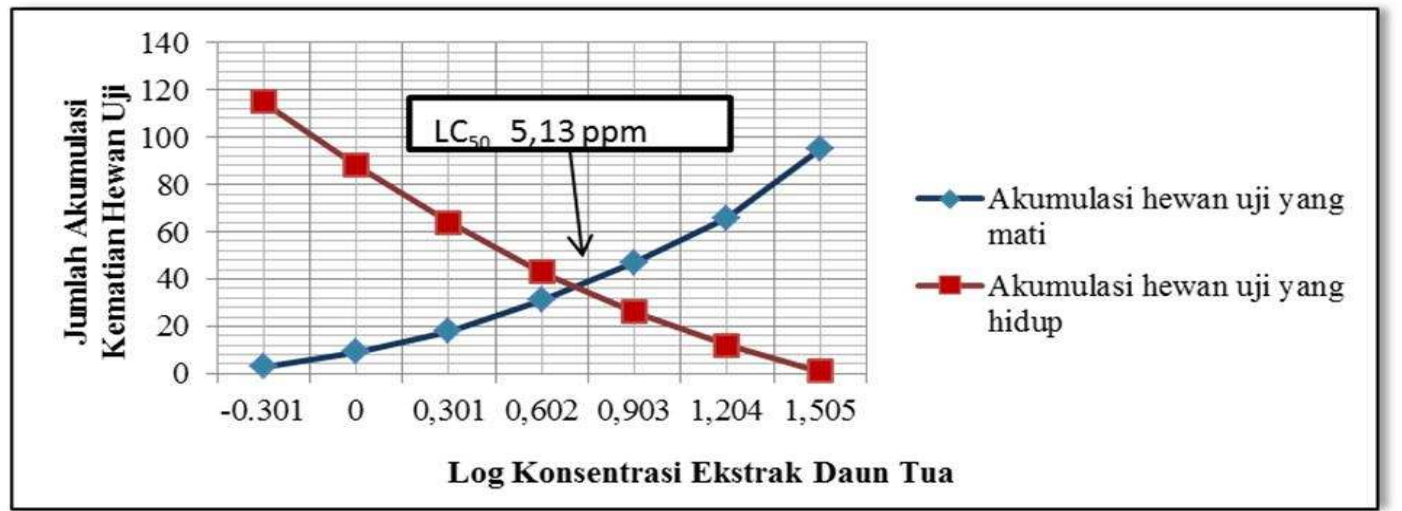

Gambar 2. LC $_{50}$ Ekstrak Air Daun Sirih Hitam Tua

Tabel 3. Nilai $L C_{50}$ Ekstrak Daun Sirih Hitam

\begin{tabular}{llc}
\hline No. & Sampel & LC $_{\mathbf{5 0}}(\mathbf{p p m})$ \\
\hline 1. & Ekstrak Daun Muda & 69,18 \\
2. & Ekstrak Daun Tua & 5,13 \\
\hline
\end{tabular}

Terlihat pada Gambar 2. terjadi peningkatan konsentrasi ekstrak air daun sirih hitam tua dalam kemampuan membunuh hewan uji larva udang, yaitu dengan bertambahnya larva udang yang mati. Ini terlihat dari hasil analisis dengan metode Reed and Muench dengan nilai $\mathrm{LC}_{50} 5,13 \mathrm{ppm}$ (Tabel.3). Estimasi nilai $\mathrm{LC}_{50}$ dapat terlihat pada grafik titik pertemuan antara akumulasi kematian dengan akumulasi yang hidup. Hasil log dari $\mathrm{LC}_{50} 5,13 \mathrm{ppm}$ adalah 0,71. Sumbu ini berada pada grafik antara log konsentrasi 0,602 - 0,903 seperti yang 
terlihat pada grafik. Hasil perhitungan batas kepercayaan angka $\mathrm{LC}_{50}$ berada antara range 0,59-0,83 dengan ukuran kesalahan sebesar 0,06. Berdasarkan nilai $\mathrm{LC}_{50}$ ekstrak air daun sirih hitam tua menunjukkan bahwa ekstrak air daun sirih hitam tua sangat berpotensi sebagai antikanker $\left(\mathrm{LC}_{50} 0-30 \mathrm{ppm}\right)$.

Dengan membandingkan nilai $\mathrm{LC}_{50}$ ekstrak daun sirih hitam dapat diketahui bahwa yang paling efektif terhadap Artemia salina Leach adalah ekstrak air daun sirih hitam tua. Berdasarkan hal tersebut dapat dikatakan bahwa aktivitas yang paling baik untuk potensi sitotoksik antikanker ditunjukkan oleh ekstrak air daun sirih hitam tua.

\section{KESIMPULAN}

Hasil pengujian potensi sitotoksik ekstrak air daun sirih hitam (Piper sp.) diperoleh nilai LC50 masing-masing yaitu ekstrak daun sirih hitam muda adalah 69,18 ppm dan ekstrak daun sirih hitam tua adalah $5,13 \mathrm{ppm}$.

\section{DAFTAR PUSTAKA}

1. Badisa, R.B.; Selina, F.; Darling-Reed, Patrick, J.; John, S.C.; Lekan, M.L.; \& Goodman, C.B. 2009. Selective Cytotoxic activities of Two Novel Synthetic Drugs on MCF-7 Cells, Anticancer Res.

2. Hastuty, R. 2011. Kandungan Metabolit Sekunder dan Bioaktivitas Terhadap Artemia salina Leach Ekstrak Daun Sirih Hitam (Piper sp.). Skripsi, Fakultas Farmasi Universitas Mulawarman : Samarinda.

3. Meyer, B.N.; et al. 1982. Brine Shrimp : A Convenient Bioassay for Active Plant Constituent. Plant Medica.

4. Rahmadhani, A. 2009. Uji Toksisitas Akut Ekstrak Etanol Daun Sukun Terhadap Artemia salina dengan Metode Brine Shrimp Lethality Test (BSLT). Fakultas Kedokteran Universitas Diponegoro: Semarang.

5. Wahyuningsih, Mae Sri Hartati. 2010. Potensi Pengembangan Obat Bahan Alam Indonesia Untuk Penyakit Kanker: Tantangan dan Harapan. Universitas Gadjah Mada: Yogyakarta. 